\title{
CHALLENGES FACED BY THE YOUTH REGARDING PARTICIPATION IN FAMILY FARMING IN PUNJAB, PAKISTAN
}

\author{
aSafdar Ali *, aGhazanfar A. Khan, aMuhammad Iftikhar, bHassan Munir \\ ${ }^{a}$ Institute of Agricultural Extension, Education and Rural Development, University of Agriculture Faisalabad, Pakistan. \\ ${ }^{b}$ Department of Agronomy, University of Agriculture Faisalabad, Pakistan.
}

\section{ART ICLE INFO}

\section{Article History}

Received: January 18, 2020

Revised: March 12, 2020

Accepted: April 27, 2020

\section{Keywords}

Family farming

Rural youth

Litigation

Agriculture

Social injustice

Generational gap
A B S T RAC T

This study was conducted in District Nankana Sahib aiming at exploring the challenges hampering the participation of rural youth in family farming. Total 360 respondents selected through snowball sampling technique were interviewed through face-to-face interview technique on a structured, validated and pretested interview schedule. Collected data were analyzed through Statistical Package for Social Sciences (SPSS). Findings unveiled that a little more than half $(56.7 \%)$ of respondents had experience of family farming surpassing over 15 years. Greater than half $(51.2 \%)$ of respondents had overwhelmed reliance on farming only in order to generate income. This study confirms that, personal factors (wandering, studentship, dependency on elders and lack of confidence), cultural (litigation, social injustice, generational gap), marketing (inflation, crashed marketing) and farming related factors (small land size, high production cost, land ownership, poor return and labour intensiveness) were the key factors hindering the participation of rural youth in family farming. This study urges a pivotal role of agricultural institutions to assist and train youth for the persuasion to join family faring. Government should be on board the policies to make agriculture a profitable venture, thus the youth can be mobilized to participate in family farming. The concept of family farming is also required to be familiarised among youth through interactive approach of media.

Corresponding Author: Safdar Ali

Email: alisafdar3002@gmail.com

(C) The Author(s) 2021.

\section{INTRODUCTION}

Agriculture as livelihood is prominent in Pakistan. Most of the Pakistan's population is engaged directly or indirectly with this noble profession. The farmers in Pakistan are connected to farming for various purposes including income for their livelihood (Ullah et al., 2019). The farmers in Pakistan are facing different challenges including lack of modern agronomic practices, low yields and shortage of water. Family farmers have the potential to compete with this challenging situation. Family-based farming is experienced based cultivation of crops (Baloch and Thapa, 2018). Family farmers have been and still the host of agricultural innovation and its sustainable adoption. They have their own piece of land, do agricultural practices and their life totally depends on agricultural activities. All members of the farmers' families are directly or indirectly involved in family based-farming (van Vliet et al., 2015).

Different factors influencing the farming are lack of confidence regarding the decision-making power, low credit, low level adoption of new agricultural technologies (Graeub et al., 2016), lack of experience, low level of education, lack of training, influence of the households' head and high rates of agricultural inputs. 
These factors are responsible to create hindrance in adopting agriculture as a profession in the farming community (Baffoe-Asare, 2013). Food insecurity, poverty, household status, age and farming technologies are influencing the farming in the farming community. The aforesaid factors are becoming the challenges for the small farmers in developing countries (Babatunde et al., 2006). Youth are the future farmers with positive thinking (Shuli et al., 2018). It is expected that youth will take over the farming land in the future in developing countries (Siddiqua et al., 2019). Youth have the potential to uplift the economic condition of family farming in Brazil (Berchin et al., 2019). Another study conducted in Brazil unveiled that youth can generate more revenue from family farmers as compared to the old farmers (Foguesatto et al., 2020). Youth have the knowledge and skills to solve agricultural problems in Europe (Brandth, 2002). In British, the stress and suicide in youth can be managed by different agricultural activities (Price and Evans, 2009). In Australia, there is a significant contribution of youth in families' income (Downey et al., 2016). Family farming can help the youth to manage the stress and, it helps them to avoid social isolation. In India, the small farmers have a great desire to quit farming and are willing to hand it over to the young generation. These kinds of farmers have strong beliefs and observations that youth can cultivate the small farming land for commercial purposes (Sharma and Bhaduri, 2009). Farming is a major source of employment for youth in Bangladesh (Islam et al., 2010). Likewise, in other countries, the youth of Pakistan has also the potential to uplift the traditional farming as modern agricultural practices (Abbas et al., 2016). The youth in developing countries including Pakistan are jobless. They have no choice to earn their living except family farming (Ahmad et al., 2020). Family-based farming can be a side business for rural youth within or after completing their education. It can provide an opportunity to the youth of developing countries to be economically independent (Olujide, 2008). Young family farmers are less attracted toward farming (Sumberg et al., 2012). Elders forced the rural youth to seek other kinds of jobs for their livelihood. The old members of the family were selling agricultural land and the youth had no or minimal area of land for cultivation. There was no secure access to agricultural land and in this way, the young generation was seeking for non-agricultural means of livelihood. Youth was trying to choose an alternate way and leaving the farming (Amanor, 2010). It is the social and moral duty of elders to support financially and provide agricultural land to their youth for their self-empowerment (Turk and Prišenk, 2013). Reasonable land size provides the chances to youth to show their hidden ability. Access to agricultural land is a necessary factor for youth to live economically independent. The youth is facing disadvantages due to low productive land (Muiruri et al., 2020).

The youth is also facing a problem like lack of economic resources. Their elders are not supporting them in the context of providing agricultural land. The provision of valuable agricultural land to youth is necessary for their self-empowerment and economic strength (Kouamé, 2010). Among the major groups of migrated people, the number of young rural people is dominant. The rural youth have a specific purpose to migrate like they are seeking for better paying jobs, better life conditions. So, lack of continuous financial sources is a reason for migration of youth from rural to urban areas (Thissen et al., 2010). The rural youth thinks that farming is not a business of grace and dignity (Webb, 2013). Rural youth have great potential to manage agricultural activities. They can learn different practices from their elders regarding family farming. Moreover, they can get education and trainings to improve their farming practices. The youth are the people of modern thinking. They have the capacity to compete with the developed world. They are the future farmers of Pakistan. There is need is to empower the youth and mitigate the factors creating the hindrance to participate the youth in family farming.

Therefore, farming for youth is difficult task in this way, youth is not agreed to take part in farming. The old farmers have no plan regarding the development after their retirement. These kinds of farmers are showing unwillingness to transfer their agricultural farms to the youth (White, 2012). The focus of the present paper was to assess the various factors which are responsible to hinder the contribution of youth in family farming.

\section{MATERIALS AND METHODS}

The present study was a part of Ph.D. research work which consisted of various objectives. It was conducted in District Nankana Sahib, Punjab, Pakistan. Multistage sampling technique was used for sample selection. Tehsil Nankana Sahib was selected purposively because it is the largest tehsil of selected district. Twenty rural 
Union Councils (UCs) were selected randomly from the selected tehsil. From each of the selected UCs, three villages were selected randomly. Three farm families were selected from each of the selected villages by using Snow-ball sampling technique. From each of the selected families, two respondents as one was the head of the farm family and second from any of the other adult family members (willing to give concerned data) were selected. In this way, the sample size was 360 respondents. A validated and reliable interview schedule was developed to probe into the true information. The data were collected by using interview schedule and analyzed through computer software i.e., Statistical Package for Social Sciences (SPSS). Mean, standard deviation, and rank order were calculated to interpret the collected data.

\section{RESULTS AND DISCUSSION}

Table 1 shows that there were a little more than one fourth $(26.1 \%)$ of the respondents with age groups of up to 25 years and a good percentage $(29.7 \%)$ of the respondents were with the age group of 26-35 years. About one fourth $(24.4 \%)$ of the respondents were 3645 years old. Great majority (75\%) of the respondents were literate up to various levels of education. But still one fourth $(25 \%)$ of the respondents were illiterate. Among the literate category, the most prominent (20.0 $\%$ ) category was primary to middle. The other categories like up to primary, middle to matriculation and above matriculation were $18.9 \%, 19.2 \%$ and $16.9 \%$ respectively. It might be concluded that great majority of the family farmers were literate, but their level of education was not very high. These findings are more or less similar to the results of Fabiyi et al. (2007) who reported that the great majority (71\%) of the respondents were literate. More than half (52.5\%) of the respondents were small farmers. A little less than one third $(30.8 \%)$ of the respondents were falling in the medium category of farmers and only $16.7 \%$ of the farmers were large farmers. Table 1 are helping to conclude that the majority (52.5\%) of the respondents were small farmers. A majority (56.7\%) of the farmers had farming experience up to 15 years. About one third (31.1\%) of the respondents had the experience up to 1630 years. About one eighth (12.2\%) of the respondents had the farming experience above 30 years. These results are in line with the findings of Edeoghon and Ajayi (2010) who found that about one third (32.2\%) of the respondents had their farming experience up to 15 30 years.

Table 1. Socio-economic characteristics of the respondents.

\begin{tabular}{|c|c|c|c|c|c|c|c|c|c|c|}
\hline Socio-economic attributes & \multicolumn{10}{|c|}{ Response } \\
\hline \multirow[t]{3}{*}{ Age (Years) } & \multicolumn{2}{|c|}{ Up to 25} & \multicolumn{2}{|c|}{$26-35$} & \multicolumn{2}{|c|}{$36-45$} & \multicolumn{2}{|c|}{$46-55$} & \multicolumn{2}{|c|}{ Above 55} \\
\hline & $f$ & $\%$ & $\mathrm{f}$ & $\%$ & $\mathrm{f}$ & $\%$ & $\mathrm{f}$ & $\%$ & $f$ & $\%$ \\
\hline & 94 & 26.1 & 107 & 29.7 & 88 & 24.4 & 38 & 10.6 & 33 & 9.2 \\
\hline \multirow[t]{3}{*}{ Education } & \multicolumn{2}{|c|}{ Illiterate } & \multicolumn{2}{|c|}{ primary } & \multicolumn{2}{|c|}{ Middle } & \multicolumn{2}{|c|}{ Matriculation } & \multicolumn{2}{|c|}{ Above matriculation } \\
\hline & f & $\%$ & $\mathrm{f}$ & $\%$ & f & $\%$ & $\mathrm{f}$ & $\%$ & $\mathrm{f}$ & $\%$ \\
\hline & 90 & 25.0 & 68 & 18.9 & 72 & 20.0 & 69 & 19.2 & 61 & 16.9 \\
\hline \multirow{3}{*}{$\begin{array}{l}\text { Size of Landholding } \\
\text { (Hectares) }\end{array}$} & \multicolumn{4}{|c|}{ Small (up to 5) } & \multicolumn{4}{|c|}{ Medium $(>5-10)$} & \multicolumn{2}{|c|}{ Large $(>10)$} \\
\hline & \multicolumn{2}{|c|}{$\mathrm{f}$} & \multicolumn{2}{|c|}{$\%$} & \multicolumn{2}{|r|}{$\mathrm{f}$} & & $\mathrm{f}$ & $\%$ \\
\hline & \multicolumn{2}{|c|}{189} & \multicolumn{2}{|c|}{52.5} & & 11 & \multicolumn{2}{|c|}{30.8} & 60 & 16.7 \\
\hline Farming Experience & \multicolumn{4}{|c|}{ Up to 15} & \multicolumn{4}{|c|}{$16-30$} & \multicolumn{2}{|c|}{ Above 30} \\
\hline \multirow[t]{2}{*}{ (Years) } & \multirow{2}{*}{\multicolumn{2}{|c|}{$\begin{array}{c}f \\
204\end{array}$}} & \multicolumn{2}{|c|}{$\%$} & & $\mathrm{f}$ & \multicolumn{2}{|c|}{$\%$} & $\mathrm{f}$ & $\%$ \\
\hline & & & & & & 12 & & .1 & 44 & 12.2 \\
\hline \multirow[t]{3}{*}{ Income sources } & \multicolumn{2}{|c|}{ Crops only } & \multicolumn{4}{|c|}{ Crops and livestock } & \multicolumn{4}{|c|}{ Crop, livestock and vegetables } \\
\hline & $\mathrm{f}$ & $\%$ & & & & $\%$ & & 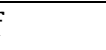 & & \\
\hline & 27 & 7.5 & & & & 1.3 & & 34 & & \\
\hline
\end{tabular}

Table 1 also depicts that more than half (51.2\%) of the respondents were depending upon crops, livestock and vegetable farming as their source of income. Still a good percentage $(41.3 \%)$ of the respondents was getting household income from crop and livestock farming. Quite a few $(7.5 \%)$ of the respondents were getting their 
household income from the crop farming only. The results of the present study are not similar with the findings of Olayemi (2012) who found that half (50\%) of the respondents were getting income from pension and other public jobs.

\section{Different common factors}

The data regarding different common factors hindering the participation of rural youth in family farming are presented in Table 2 .

Table 2. Personal factors hindering the participation of youth in family farming.

\begin{tabular}{lcc}
\hline Personal factors & Mean \pm Standard Deviation & Rank Order \\
\hline Wandering & $4.18 \pm 1.126$ & 1 \\
Studentship & $3.99 \pm 1.069$ & 2 \\
Dependency on elders & $3.95 \pm 1.061$ & 3 \\
Lack of confidence & $3.83 \pm 1.119$ & 4 \\
Demotivation & $3.74 \pm 1.297$ & 5 \\
Laziness or inconsistency & $3.67 \pm 1.203$ & 6 \\
Vulnerability to disease & $1.71 \pm 0.830$ & 7 \\
Physically challenged & $1.71 \pm 0.479$ & 7 \\
\hline
\end{tabular}

Scale: $1=$ Strongly disagree, $2=$ Disagree, $3=$ Somewhat agree, $4=$ Agree, $5=$ Strongly agree

Table 2 depicts personal factors creating hindrance to participate in family farming. Wandering was ranked 1 st $(\bar{X}=4.18 \pm 1.126)$ in sense of lowering the participation of rural youth in family farming. The mean value fell between agree and strongly agree category but tended towards agree. This is due to the fact that rural youth are not serious to participate in the family farming, the reason may be that they are irresponsible and beloved of their parents. One of the respondents revealed that they are not willing that their young one's work with them. Another respondent unveiled that we wish that our children (youth) should be educated. These findings are similar to those of the results of Dietz et al. (2013) who revealed in their study that the rural youth had no specific purpose and they wandered in groups so, avoiding the family farming. Studentship was occupying the second position $(\overline{\mathrm{X}}=3.99 \pm 1.069)$ to hinder the participation of rural youth in family farming. The rural youth were busy in study and not participating in family based-farming due to limited time. One of the young respondents explored that there is no secondary school and college in our rural areas, they have to move towards the city for their education. Poor transportation and bad road conditions are time consuming. Sometimes they stayed in hostels for the preparation of their exams so, they have no time for participating in family farming. These results are in line with those of Kaplan et al. (2009) who revealed that studentship is a prominent factor to hinder the rural youth to participate in family farming-based activities. The 3rd position was occupied by dependency on elders $(\bar{X}=3.95 \pm 1.061)$ and it was hindering the rural youth to participate in family farming. The mean value fell between somewhat agree and agree but more tended towards agree. The rural youth were depending on their elders in the sense of pocket money, necessary shopping. Youth was also bound to obey the order of their elders. In this way, youth were not independent to participate in various activities of family-based farming. These findings are in consonance with the results of Daxini et al. (2018) who concluded that dependency of youth on their elders hindering the youth to become farmers. Lack of confidence was ranked at 4 th position $(\bar{X}=3.83 \pm 1.119)$ the mean value lies between somewhat agree and agree but tended more towards agree. It may be inferred that the respondents agreed that the rural youth are victims of low level of confidence to participate in family farming. The reason may be that the elders were holding the power in their hands regarding the farming activities. Moreover, the youth were participating in family-based activities occasionally which was creating inconsistency and the result was low level of confidence in youth to participate in family farming. Demotivation was ranked at 5 th position $(\bar{X}=3.74 \pm 1.297)$ the mean value fell between somewhat agree and agree category of response but tended more towards agree. The supposition is that the rural youth were not inspired by their peers to participate in family farming. Most of their peer were found of playing and some kinds of entertainment activities so, youth were demotivated 
(Riley, 2016) to participate in family-based farming. Laziness or inconsistency was ranked at $6^{\text {th }}$ position $(\bar{X}=3.67 \pm 1.203)$ to hinder the youth' participation in family farming. Mean value lies between somewhat agree and agree but tended more towards agree. It unveiled that the rural youth were showing inconsistency in their behavior towards family farming. One of the respondents said that farming is a scheduled and routine based activity. It needed proper attention and time (Driessen and Heutinck, 2014) but the youth are not understanding the critical point of this situation. So, the elders did not believe in youth to do proper farming activities. Vulnerability to disease and physically challenged both of the factors were ranked at $7^{\text {th }}$ positions $(\overline{\mathrm{X}}=1.71 \pm 0.830)$ and $(\overline{\mathrm{X}}=1.71 \pm 0.479)$ respectively. Mean values lie between strongly disagree and disagree but more tended towards disagree. It may be inferred that the rural youth were physically fit and they were not the victim of any disease. These last said two factors were not hindering the participation of youth in family farming. Table 1 concludes wandering, studentship, laziness or inconsistency, demotivation of the youth towards the farming where the prominent factors hinder the youth to participate in family farming.

Table 3. Marketing, cultural and other relevant factors hindering the participation of youth in family farming.

\begin{tabular}{lcc}
\hline Marketing, cultural and other relevant factors & Mean \pm St. Dev. & Rank Order \\
\hline Inflation & $4.34 \pm 0.942$ & 1 \\
Unwillingness to sacrifice their wishes & $4.00 \pm 1.245$ & 2 \\
Litigation & $3.94 \pm 1.221$ & 3 \\
Non-involvement of youth in decision making process in farming & $3.93 \pm 1.225$ & 4 \\
Youth preference on income generating activities & $3.92 \pm 1.248$ & 5 \\
Social injustice & $3.78 \pm 1.120$ & 6 \\
Communication gap between youth and elders & $3.76 \pm 1.093$ & 7 \\
Unnecessary use of social media & $3.76 \pm 1.213$ & 8 \\
Absence of success stories regarding family farming & $3.74 \pm 1.274$ & 9 \\
Poor access to agricultural markets & $3.73 \pm 1.454$ & 10 \\
Brain drains & $3.65 \pm 1.419$ & 11 \\
Undo criticism on youth's work & $3.58 \pm 1.418$ & 12 \\
Selling of land for money & $3.56 \pm 1.265$ & 13 \\
Urbanization & $3.52 \pm 1.316$ & 14 \\
Generational difference & $3.36 \pm 1.372$ & 15 \\
\hline
\end{tabular}

Scale: $1=$ Strongly disagree, $2=$ Disagree, $3=$ Somewhat agree, $4=$ Agree, $5=$ Strongly agree

\section{Marketing, cultural and other relevant factors}

Table 3 reveals the marketing, cultural and other relevant factors were responsible to create hindrance in youth to participate in family farming. Inflation $(\bar{X}=4.34$ $\pm 0.942)$ was ranked $1^{\text {st }}$ position. Mean value lies between agree and strongly agree but tended towards agree. The supposition is that the family farmers were facing challenges including inflation. Youth can uplift their family income (Juang et al., 2017). Family farmers want that their children (youth) should be highly educated and they earn a handsome amount. So, the family farmers are not inclined towards the participation of their youth in family farming. It may lead towards unwillingness to sacrifice their wishes $(\bar{X}=4.00 \pm 1.245$ ) ranked 2nd in sense of factors to hinder the youth's participation in family farming. Mean value lies on agree category of response. The youth are the people having the maximum level of energy. They are the early decisions taker. Litigation $(\overline{\mathrm{X}}=3.94 \pm 1.221)$ was ranked at $3^{\text {rd }}$ position as hindering factor to the participation of youth in family farming. Mean value lies between somewhat agree and agree but tended towards agree. During informal discussion, the respondents revealed, there are various types of litigation in rural areas including local politics, property disputes, torts and class action. The youth are the active members of these conflicts. Young people are involved in litigation due to canal water supply and agricultural land disputes; they are also facing social conflict like murder and other unhealthy social activities. Some of the young people are 
facing police cases due to quarrelling in the village areas. Due to conflicts and other kinds of litigation youth were not taking part in family farming. Non-involvement of youth in the decision-making process in farming ( $\overline{\mathrm{X}}=$ $3.93 \pm 1.225$ ) was occupying the $4^{\text {th }}$ position in sense of the factors hinder youth to participate in family farming. Mean value fell between somewhat agree and agree but tended more towards agree. Family farmers make different decisions including cultivation of crops, use of different cropping technology, installation of tube wells, purchasing and selling of animals, agricultural machinery and different indoor activities. Elder family members were involved in decision making and they often order young ones to walk out the proceedings. This typical behaviour of elders developed the lack of confidence in youth (Kuehne, 2012). Youth preference on income generating activities $(\overline{\mathrm{X}}=$ $3.92 \pm 1.248$ ) was ranked at 5 th position, mean value fell between somewhat agree and agree but tended more towards agree. It may be due to the fact that youth need money for multipurpose necessities and they are unable to fulfill their needs due to dependency on their elders. So, youth want to earn money for their own needs. Social injustice $(\overline{\mathrm{X}}=3.78 \pm 1.120)$ was ranked at 6 th position and communication gap between youth and elders $(\overline{\mathrm{X}}=$ $3.76 \pm 1.093$ ) was ranked at 7 th position. It is concluded that youth are facing challenges of social injustice including a poor physical environment; financial and health problems and poor educational opportunities. Moreover, youth are exposed to spoken of loneliness, lack of love and emotional attachment to their families and afraid of speaking up which is a strong cause of lack of communication between youth and elders. Due to social injustice youth can be suppressed and they cannot express their area of interest even participation in family farming. Unnecessary use of social media $(\bar{X}=3.76 \pm$ 1.213) was also ranked at $7^{\text {th }}$ position. The mean value fell between somewhat agree and agree but tended towards agree. Absence of success stories regarding family farming $(\overline{\mathrm{X}}=3.74 \pm 1.274)$ was ranked at $8^{\text {th }}$ position, mean value fell between somewhat agree and agree but tended more towards agree. It is inferred that the youth were using social media including Facebook, WhatsApp and Instagram unnecessarily. Youth were wasting time and disinterested in family farming. So, there was no success story of young family farmers to inspire their peers. Poor access to agricultural markets $(\bar{X}=3.73 \pm 1.454)$ was occupying 9 th position in sense of factors to hinder the participation of youth in family farming". One of the young respondents said, "we are well aware of the poor condition of roads and agricultural markets, it has no attraction for farmers so, we are not participating in family farming. Youth was tending towards brain drain $(\overline{\mathrm{X}}=3.65 \pm 1.419)$ ranked at $10^{\text {th }}$ position. The mean value lies between somewhat agree and agree but tended towards agree. Young people had no interest in family farming and wanted to go abroad for study and earning. Undo criticism on youth's work $(\bar{X}=3.58 \pm 1.418)$ occupied 11 th position regarding the hindering factors to participation of youth in family farming. It is concluded that elders were not satisfied with youth work. Youth had been criticized and not encouraged by elders. Elders were not role models for youth. Moreover, youth were frustrated and feeling odd to work under criticism (Fine et al., 2007). Selling of land for money $(\bar{X}=3.56 \pm 1.265)$ and urbanization $(\bar{X}=3.52 \pm$ 1.316) were ranked at 12 th and 13 th position respectively in sense of hindering factors to participate the youth in family farming. It may be inferred that output from family farming was very low and the farmers were selling agricultural land to survive in the society (Zollinger and Krannich, 2009). The land was being purchased by the business men and they were making residential colonies. So, the youth were facing the challenge of poor access to agricultural land. These results are almost similar with those of Kouamé (2010). He concluded that youth were facing a challenge like lack of economic resources. Their elders were not supporting them in the context of providing agricultural land. The provision of valuable agricultural land to youth is necessary for their self-empowerment and economic strength. Generational gap $(\bar{X}=3.36 \pm 1.372)$ was at the bottom as a factor to hinder the participation of youth in family farming. Mean value lies between somewhat agree and agree but tended towards somewhat agree. The supposition is that the differences in beliefs, opinions, and in the values between different generations of people is a hurdle for youth to participate in family farming. It is also affecting the social and political life of youth (Sun and Wang, 2010). Generational gap is an important hindering to youth concerning the participation of family farming. It has greatly influenced different generations to adopt any professions and innovations. The old generation has a minimum level of education as compared to youth in Pakistan. The old generation are influencing youth in 
every sphere of the life. So, youth are bound to the

thinking of old generation due to cultural issues.

Table 4. Farming related factors hindering the participation of youth in family farming.

\begin{tabular}{lcc}
\hline Farming related factors & Mean \pm Std. Dev. & Rank Order \\
\hline Small land holdings & $4.97 \pm 1.017$ & 1 \\
High production cost & $4.95 \pm 1.095$ & 2 \\
Crashed/defective marketing & $4.83 \pm 1.299$ & 3 \\
Land ownership & $4.02 \pm 1.307$ & 4 \\
Avoiding behavior of youth regarding farming & $3.90 \pm 1.154$ & 5 \\
Poor agricultural return & $3.84 \pm 1.101$ & 6 \\
Inadequate access to Agricultural information & $3.76 \pm 1.210$ & 7 \\
Unfertile land & $3.65 \pm 1.315$ & 8 \\
Labour intensive & $3.59 \pm 1.336$ & 9 \\
Lack of adequate agricultural understanding & $3.15 \pm 1.088$ & 10 \\
\hline
\end{tabular}

Scale: 1 = Strongly disagree, $2=$ Disagree, $3=$ Somewhat agree, 4= Agree, 5= Strongly agree

Table 4 depicts that small landholdings ( $\overline{\mathrm{X}}=4.97 \pm 1.017$ ) was ranked at the uppermost position regarding farming related factors to hinder the participation of youth in family farming. The mean value lies between agree and strongly agree but tends more towards strongly agree. It may be due to that there is generation to generation division of land in Pakistan. The land of the parents transfers to their children (youth). This kind of land division leads towards small land to the next generation. Youth with small land is not interested in family farming as there is poor returns and it is near to impossible to live with a small piece of agricultural land for rural youth (Bezu and Holden, 2014). High production cost ( $\bar{X}=4.95$ $\pm 1.095)$ was ranked at 2 nd position. The high production cost (Calus and Huylenbroeck, 2010) is a prominent factor to hinder the rural youth's participation in family farming. The supposition is that the production cost demands net money but the farmers often don't have so it leads to lower the interest in the participation of family farming. Crashed/defective marketing ( $\bar{X}=4.83 \pm 1.299$ ) was ranked at 3rd position in sense of hinder to youth in participation in family farming. It can be inferred that the sudden crash or defection in the market is not supporting to the youth to participate in family farming. Youth are the keen observers (Labaree, 2002), energetic and they can reach the results to observe something. They are well aware to the sudden crash of agricultural markets and feel the loses. This is a situation which hinders them from participating in family farming. One of the young respondents disclosed, agricultural markets have no consistency in the price of the production. High production cost cannot be met through the selling of agricultural products in the crashed markets. The family farmers are helpless to get proper rates. Land ownership $(\bar{X}=4.02 \pm 1.307)$ was occupying the 4 th position, the mean value fell between agree and strongly agree but tended more towards agree. Land ownership is a status symbol in rural areas (Chenevix-Trench and Philip, 2001). The old farmers were not willing to transfer the ownership of land to their youth. The elders were afraid of the non-serious behavior of the youth regarding farming. This may be due to the overthinking of the elders that the youth can sell the agricultural land to enjoy life. Common remarks of the old respondents, "if we transfer the ownership of land to youth, we will lose dignity in our lives, if transfer the ownership of land to youth. Youth is not trustworthy, they can sell the land to purchase a car, mobile phone, and spoil the money". It may be concluded that the youth were not the legal owners of agricultural land. Avoiding behavior of youth $(\bar{X}=3.90 \pm 1.154)$ regarding farming was ranked at 5th position. The mean value lies between somewhat agree and agree but tended toward agree. It may be concluded that the youth show such kind of behavior to avoid participating in family farming activities. The reason of their avoiding behavior regarding family farming may be poor agricultural return $(\overline{\mathrm{X}}=3.84 \pm 1.101)$. Agricultural production was low as compared to the inputs. Low rates, defective markets, poor transportation (Clark and Tilman, 2017) was the cause of poor agricultural return, resultantly low level of participation of youth in familybased farming activities. There was another challenge may be the reason of poor agricultural return and 
youth's participation in family farming including inadequate access to agricultural information $(\overline{\mathrm{X}}=3.76 \pm$ 1.210) was ranked at $7^{\text {th }}$ position. Mean value fell between somewhat agree and agree but tended more towards agree. The poor agricultural extension services and lack of information regarding better crops and production technology were also the hindering factors to force the youth to show avoiding behavior to take part in family farming as regular basis and like professionals. Another factor was low soil fertility or unfertile land $(\bar{X}=3.65 \pm 1.315)$ was ranked at 8 th position, its mean value lies between somewhat agree and agree but tended more towards agree. It may be inferred that some of the respondents were having low fertile or unfertile land to some extent. These results are somewhat similar with the findings of (Muiruri et al., 2020) who found that the youth is facing disadvantages due to low productive land. Due to low fertility of land, they are unable to do modern farming. So, the youth were not willing to participate in the family farming. The other reason may be that labour intensive $(\bar{X}=3.59 \pm$ 1.336) was ranked at 9 th position. The mean value lies between somewhat agree and agree but tended towards agree. Cultivation of land requires physical efforts and mental attention. Moreover, the cultivation of unfertile land needs more efforts, knowledge, skills and attention. So, the youth are not accustomed to work hard in the farm related activities. That's why the youth were not willing to do family farming. Due to lack of participating in family farming related activities and low level of practical knowledge, youth were embedded in the situation of lack of adequate agricultural understanding $(\bar{X}=3.15 \pm 1.088)$ was ranked at 10 th position, mean value lies between somewhat agree and agree but tended more towards somewhat agree. It may be inferred that youth had no adequate agricultural understanding due to disinterest in agriculture. So, youth were avoiding from participating in family farming.

\section{CONCLUSIONS}

Youth is an important asset for the future of family farming. The sustainability of family farming depends on youth, living in village areas. But findings of this paper indicate a very disappointing situation due to different factors which were inviting a number of challenges associated with youth participation in family farming including alienation from their communities and ritual engagement in family farming. Common factors included wandering, studentship, demotivation and lack of confidence. Prominent marketing and cultural factors included inflation, litigation, social injustice and poor access to agricultural markets. The farming related prominent factors, responsible for poor contribution of rural young people in family farming included small landholdings, high production rates, crashed markets and labour insensitivity further the youth were not the land owners through legal means. The proponents of family farming should made local councils or forums to give young people the opportunity (could be in the form of agri. technology and social media) to build their capacity regarding family farming.

\section{REFERENCES}

Abbas, A., T. S. Amjath-Babu, H. Kächele and K. Müller. 2016. Participatory adaptation to climate extremes: an assessment of households' willingness to contribute labor for flood risk mitigation in Pakistan. Journal of Water and Climate Change, 7: 621-36.

Ahmad, S., W. Huifang, S. Akhtar, S. Maqsood and S. Imran. 2020. An analytical study of child labour in the agriculture sector of the rural areas of central Punjab, Pakistan. Sri Lanka Journal of Social Sciences, 43: 21.

Amanor, K. S. 2010. Family Values, Land Sales and Agricultural Commodification in South-Eastern Ghana. Africa, 80: 104-25.

Babatunde, R. O., O. A. Omotesho and O. S. Sholotan. 2006. Socio-Economics Characteristics and Food Security Status of Farming Households in Kwara State, North-Central Nigeria. Pakistan Journal of Nutrition, 6: 49-58.

Baffoe-Asare, R. 2013. Socioeconomic Factors Influencing Adoption of Codapec and Cocoa High-tech Technologies among Small Holder Farmers in Central Region of Ghana. American Journal of Experimental Agriculture, 3: 277-92.

Baloch, M. A. and G. B. Thapa. 2018. The effect of agricultural extension services: Date farmers' case in Balochistan, Pakistan. Journal of the Saudi Society of Agricultural Sciences, 17: 28289.

Berchin, I. I., N. A. Nunes, W. S. de Amorim, G. A. Alves Zimmer, F. R. da Silva, V. H. Fornasari, M. Sima and J. B. S. O. de Andrade Guerra. 2019. The 
contributions of public policies for strengthening family farming and increasing food security: The case of Brazil. Land Use Policy, 82: 573-84.

Bezu, S. and S. Holden. 2014. Are Rural Youth in Ethiopia Abandoning Agriculture? World Development, 64: 259-72.

Brandth, B. 2002. Gender Identity in European Family Farming: A Literature Review. Sociologia Ruralis, 42: 181-200.

Calus, M. and G. V. Huylenbroeck. 2010. The Persistence of Family Farming: A Review of Explanatory Socio-economic and Historical Factors. Journal of Comparative Family Studies, 41: 639-60.

Chenevix-Trench, H. and L. J. Philip. 2001. Community and conservation land ownership in highland Scotland: A common focus in a changing context. Scottish Geographical Journal, 117: 139-56.

Clark, M. and D. Tilman. 2017. Comparative analysis of environmental impacts of agricultural production systems, agricultural input efficiency, and food choice. Environmental Research Letters, 12: 064016.

Daxini, A., C. O'Donoghue, M. Ryan, C. Buckley, A. P. Barnes and K. Daly. 2018. Which factors influence farmers' intentions to adopt nutrient management planning? Journal of Environmental Management, 224: 350-60.

Dietz, A., K. v. d. Geest, F. Obeng and J. Yaro. 2013. Local perceptions of development and change in Northern Ghana. In, Rural development in northern Ghana.

Downey, H., G. Threlkeld and J. Warburton. 2016. How do older Australian farming couples construct generativity across the life course?: A narrative exploration. Journal of Aging Studies, 38: 57-69.

Driessen, C. and L. F. M. Heutinck. 2014. Cows desiring to be milked? Milking robots and the co-evolution of ethics and technology on Dutch dairy farms. Agriculture and Human Values, 32: 3-20.

Edeoghon, C. O. and M. T. Ajayi. 2010. An assessment of agricultural enterprises owned by women farmers in Ikpoba-Okha local government, Edo state, Nigeria. Global Journal of Agricultural Sciences, 8.

Fabiyi, E. F., B. B. Danladi, K. E. Akande and Y. Mahmood. 2007. Role of Women in Agricultural Development and Their Constraints: A Case
Study of Biliri Local Government Area, Gombe State, Nigeria. Pakistan Journal of Nutrition, 6: 676-80.

Foguesatto, C. R., G. d. V. Mores, S. Dalmutt Kruger and C. Costa. 2020. Will I have a potential successor? Factors influencing family farming succession in Brazil. Land Use Policy, 97: 104643.

Graeub, B. E., M. J. Chappell, H. Wittman, S. Ledermann, R. B. Kerr and B. Gemmill-Herren. 2016. The State of Family Farms in the World. World Development, 87: 1-15.

Islam, M., S. Takashi and K. N. Chhabi. 2010. Women's contribution to self-financed small-scale independent broiler farming and their participation in farm extension activities in rural Bangladesh. Livestock Research for Rural Development, 22.

Juang, L. P., J. Simpson, R. M. Lee, A. Rothman, P. F. Titzmann, M. K. Schachner, L. Korn, D. K. Heinemeier and C. Betsch. 2017. Using Attachment and Relational Perspectives to Understand Adaptation and Resilience among Immigrant and Refugee YouthCenter for Open Science.

Kaplan, M. S., J. F. Nussbaum, J. C. Becker, C. Fowler and M. J. Pitts. 2009. Communication barriers to family farm succession planning. Journal of extension, 47: 1-9.

Kouamé, G. 2010. Intra-Family and Socio-Political Dimensions of Land Markets and Land Conflicts: The Case of the Abure, Côte d'Ivoire. Africa, 80: 126-46.

Kuehne, G. 2012. My decision to sell the family farm. Agriculture and Human Values, 30: 203-13.

Labaree, R. V. 2002. The risk of 'going observationalist': negotiating the hidden dilemmas of being an insider participant observer. Qualitative Research, 2: 97-122.

Muiruri, M. W., F. P. Mathenge and D. J. Ntale. 2020. Management Strategies and The Performance of Youth Agri-Businesses in Kenya: A Case of Farm Africa. Journal of Entrepreneurship and Project Management, 5: 59-83.

Olayemi, A. O. 2012. Effects of family size on household food security in Osun State, Nigeria. Asian journal of agriculture and rural development, 2: 136-41. 
Olujide, M. G. 2008. Attitude of Youth Towards Rural Development Projects in Lagos State, Nigeria. Journal of Social Sciences, 17: 163-67.

Price, L. and N. Evans. 2009. From stress to distress: Conceptualizing the British family farming patriarchal way of life. Journal of Rural Studies, 25: 1-11.

Riley, M. 2016. How does longer term participation in agri-environment schemes [re]shape farmers' environmental dispositions and identities? Land Use Policy, 52: 62-75.

Sharma, A. and A. Bhaduri. 2009. The "tipping point" in Indian agriculture: Understanding the withdrawal of the Indian rural youth. Asian Journal of Agriculture and Development, 6: 8397.

Shuli, F., A. H. Jarwar, X. Wang, L. Wang and Q. Ma. 2018. Overview of the Cotton in Pakistan and its Future Prospects. Pakistan Journal of Agricultural Research, 31.

Siddiqua, A., M. Ahmad and N. Habib. 2019. Farmers Adaptation Strategies to Combat Climate Change Impacts on Wheat Crop in Pakistan. Pakistan Journal of Agricultural Research, 32.

Sumberg, J., N. A. Anyidoho, J. Leavy, D. J. H. te Lintelo and K. Wellard. 2012. Introduction: The Young People and Agriculture 'Problem' in Africa. IDS Bulletin, 43: 1-8.

Sun, J. and X. Wang. 2010. Value differences between generations in China: a study in Shanghai. Journal of Youth Studies, 13: 65-81.
Thissen, F., J. D. Fortuijn, D. Strijker and T. Haartsen. 2010. Migration intentions of rural youth in the Westhoek, Flanders, Belgium and the Veenkoloniën, The Netherlands. Journal of Rural Studies, 26: 428-36.

Turk, A. B. Z. B. J. and J. Prišenk. 2013. The succession status of family farms in the Mediterranean region of Slovenia. Sociológia, 45: 316-37.

Ullah, W., M. Nafees, M. Khurshid and T. Nihei. 2019. Assessing farmers' perspectives on climate change for effective farm-level adaptation measures in Khyber Pakhtunkhwa, Pakistan. Environmental Monitoring and Assessment, 191.

van Vliet, J. A., A. G. T. Schut, P. Reidsma, K. Descheemaeker, M. Slingerland, G. W. J. van de Ven and K. E. Giller. 2015. De-mystifying family farming: Features, diversity and trends across the globe. Global Food Security, 5: 11-18.

Webb, P. 2013. Impact pathways from agricultural research to improved nutrition and health: literature analysis and research priorities. Rome: Food and Agriculture Organization and Geneva: World Health Organization.

White, B. 2012. Agriculture and the Generation Problem: Rural Youth, Employment and the Future of Farming. IDS Bulletin, 43: 9-19.

Zollinger, B. and R. S. Krannich. 2009. Factors Influencing Farmers' Expectations to Sell Agricultural Land for Non-Agricultural Uses*. Rural Sociology, 67: 442-63. 